\title{
STATISTICAL STUDY OF FATAL BLUNT HEAD INJURIES IN GREAT CAIRO GOVERNORATE DURING 2014
}

\author{
By \\ Rageh Reda Abdullah Awara*, Fouad Helmy El -Dabah \\ and Ashraf Ibrahim Hassan,**
}

Forensic Medicine Council, Ministry of Justice*, and Department of Forensic Medicine and Clinical Toxicology**, Al-Azhar Faculty of Medicine

\begin{abstract}
Backgrounds: Of all regional injuries, those of the head and neck are the most common and most important in forensic practice. The head is the target of choice in the great majority of assaults involving blunt trauma. When the victim is pushed or knocked to the ground, he often strikes his head. The brain and its coverings are vulnerable to degrees of blunt trauma that would rarely be lethal if applied to other body areas.
\end{abstract}

Objective: Study aimed to find out incidence and medico legal aspects of fatal blunt head injury to identify characters and magnitude of the problem to design a plan for better control of the problem.

Subjects and method: Study was carried out retrospectively through collecting data from post-mortem report of all fatal blunt head injuries cases autopsied in Zeinhom mortuary during 2014. The variables considered were age and gender of victim, cause and manner of death, type of weapon, types of skull fractures, and seasonal variation.

Results: The studied group represented 129 cases out of total 2,128 cases that had been examined in Zeinhom mortuary during 2014. The highest incidence of head injury was seen in victims of $3^{\text {rd }}$ and $4^{\text {th }}$ decades (79 victims; $60 \%)$. The majority were males $(99 ; 76 \%)$. Ninety three cases $(72 \%)$ were victims of homicide, while suicidal cases were $16(12.4 \%)$, and accidental fatal head trauma victims were $20(15.5 \%)$.

Conclusion: Blunt trauma to the head is still a relevant challenge for the forensic pathologist who must obtain a complete and accurate history of the crime (including details regarding the crime scene), interpret patterns of injury and other findings at autopsy, and correlate all of the findings to make an accurate ruling of the cause and manner of death.

Key words: Blunt injury, head, fatal, Cairo.

\section{INTRODUCTION}

Blunt force trauma is one of the most common injuries encountered by the forensic pathologist in a variety of scenarios such as transportation fatalities, jumping or falling from heights, blast injuries, and being struck by firm objects. Blunt force injuries located in the cranium are often associated with the cause of death which makes their examination of vital importance in the medicolegal investigation of death (Kranioti, 2015). Cranio-cerebral injuries (also known as head injuries), one of the most important regional injuries, were known to human beings since time immemorial. In the 
modern era also, they are increasingly encountered worldwide day by day. Not only in developing countries but also in the developed countries, fatal head injuries are becoming the most common cause of death from trauma. It has a huge medical, social and economic bearing of the country as it involves especially younger age group population (Hemalatha and Singh, 2013).

According to the World Health Organization, traumatic brain injury (TBI) will lead as the major cause of death and disability by the year 2020. It is estimated that 10 million people were affected annually by TBI (Calvin et al., 2012).

The global incidence of fatal head injuries as the result of assault is greater than the number of non-fatal cases. The important factors that determine the outcome in terms of survival of such head injury cases include the type of weapon used, type and site of skull fracture, intra cranial hemorrhage and the brain injury. Inflicting injury to the head is one of the most effective methods of homicide (Chattopadhyay and Tripathi, 2010).

The present study was a retrospective study through post-mortem report data of all fatal blunt head injuries cases examined in Zeinhom mortuary during 2014. Our aim was to find out incidence and medico-legal aspects of these cases to identify character of head injuries and magnitude of the problem which may help to design a plan for better control of the problem.

\section{SUBJECTS AND METHODS}

This study was based on analysis of autopsy reports of fatal traumatic head injuries that had been examined in Zeinhom mortuary during 2014. The collected data from the studied group which represented 129 cases of total 2,128 cases were subjected to both epidemiological and medico-legal analysis as follows:

\section{I) Epidemiological analysis:}

- Age of the victims.

- Gender of the victims.

- Seasonal variation.

II) Medicolegal analysis and pattern of fatal traumatic head injuries:

- Type of traumatic head injuries whether blunt head injury alone or head injury associated with other types of injuries.

- The causative agents whether wooden stick, brick, falling from height .or other blunt objects.

- Manner and mechanism of death.

- The collected data were tabulated and analysed and graphically represented.

\section{RESULTS}

Age distribution: As shown in figure (1), the highest incidence of head injury was seen in victims of $3^{\text {rd }}$ and $4^{\text {th }}$ decades, i.e. 79 victims which exceeded $60 \%$ of total victims, while the least age was seen in $2^{\text {nd }}$ age group, i.e. 7 cases $(5.43 \%)$, elder victims were 9 victims $(6.98 \%)$, and $1^{\text {st }}$ decade victims were 10 victims $(7.75 \%)$. 


\section{STATISTICAL STUDY OF FATAL BLUNT HEAD INJURIES IN GREAT CAIRO... 91}

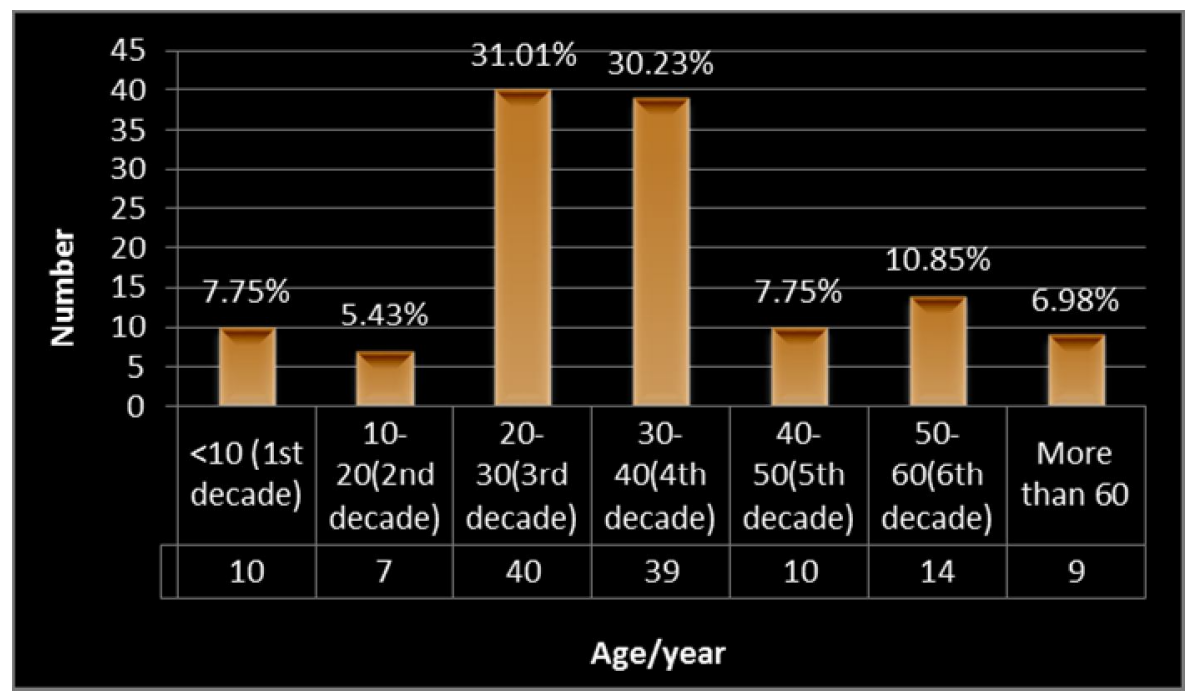

Figure (1): Distribution of the victims of blunt head trauma according to the age of the victims.

Sex and sex- age distribution: Male victims of fatal blunt head trauma were the majority victims, 99 out of the total 129 with a percentage of more than $76 \%$ (Table 1). Sixty four of victims were in $3^{\text {rd }}$ and $4^{\text {th }}$ decades $(65 \%)$ while 15 cases

\begin{tabular}{|l|l|l|}
\hline Gender & Number & $\%$ \\
\hline Males & 99 & 76.74 \\
\hline Females & 30 & 23.26 \\
\hline Total & 129 & 100.0 \\
\hline
\end{tabular}
out of 30 cases of females were in $3^{\text {rd }}$ and $4^{\text {th }}$ decades' age (50\%-figure 2$)$.

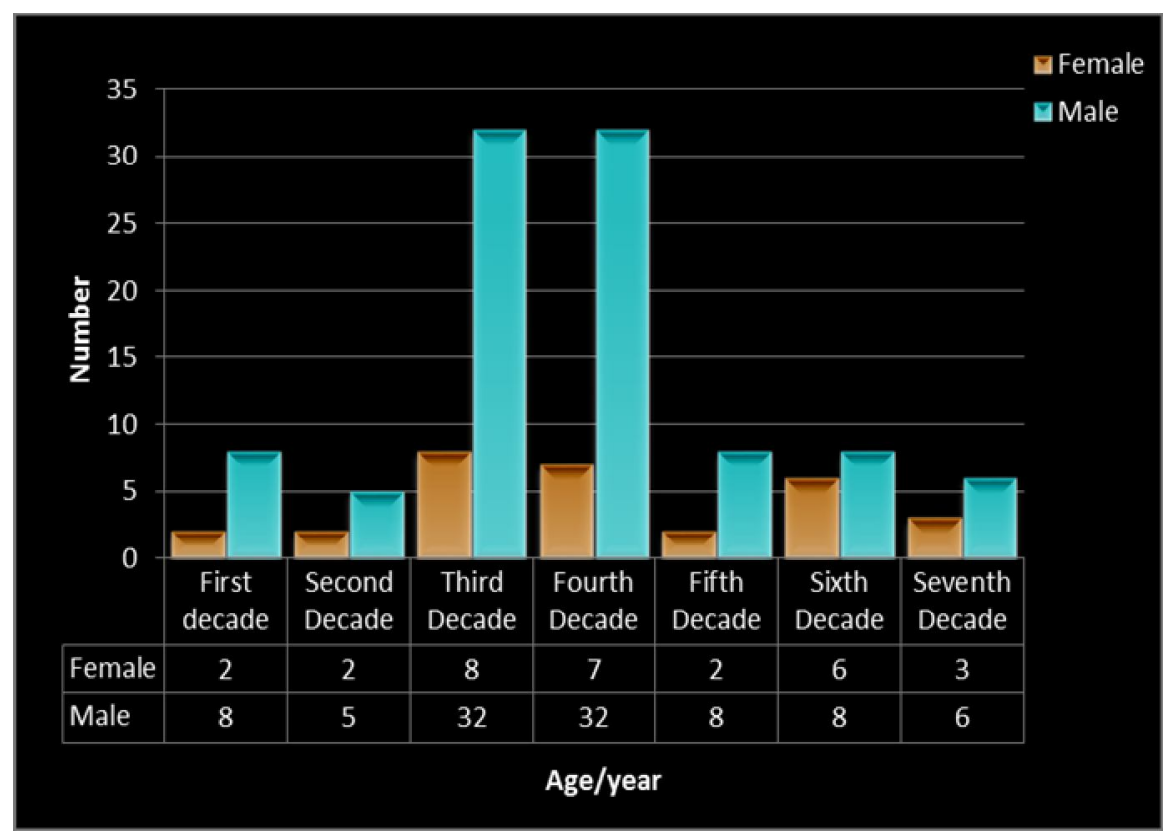

Figure (2): Distribution of victims according to the age in males and females 
Mechanism of death: As regards mechanism of death, intracranial hemorrhage and brain injury were present in majority of cases (figure 3-110; $85,27 \%$ ), while in 10 cases intracranial hemorrhage was the only finding and in 9 cases encephalitis was evident.

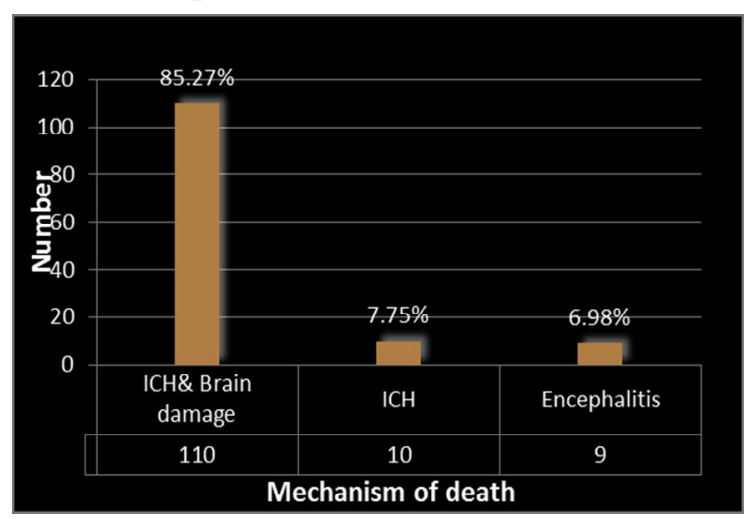

Figure (3): Distribution of the studied group according to the mechanism of death.

Manner of death: Figure (4) showed that $93(72 \%)$ cases were homicidal blunt head trauma victims, while suicidal cases were $16(12.4 \%)$, and accidental fatal head trauma victims were $20(15.5 \%)$.

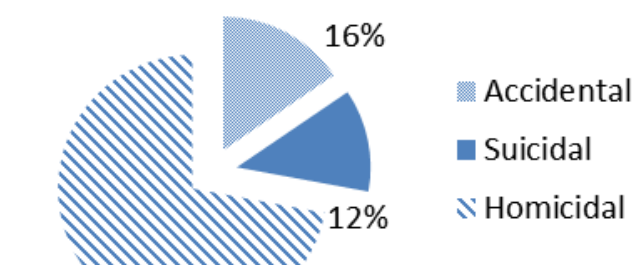

$72 \%$

Figure (4): Distribution of the studied group according to the manner of death.

Types of skull fractures: Fissure fractures were found in 46 cases. In only 6 cases depressed fractures were seen without fissures, while both types of fractures were seen in 67 cases (about
$52 \%$ ). It is worth noting that, in 10 cases of blunt head trauma, no bone fractures were found (figure 5).

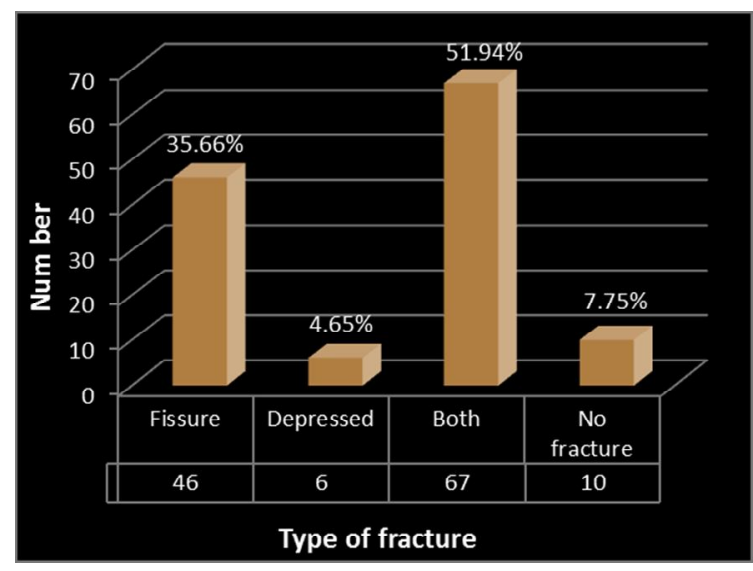

Figure (5): Distribution of the studied group according to type of fracture.

Causative agents: Falls as a cause to head trauma and death were found in 28 victims (22\%), 24 cases $(18.6 \%)$ were hit by stick. In 7 cases $(5.43 \%)$ the causative agent was brick while other blunt objects were used to traumatize 70 victims (54.26\%-figure 6).

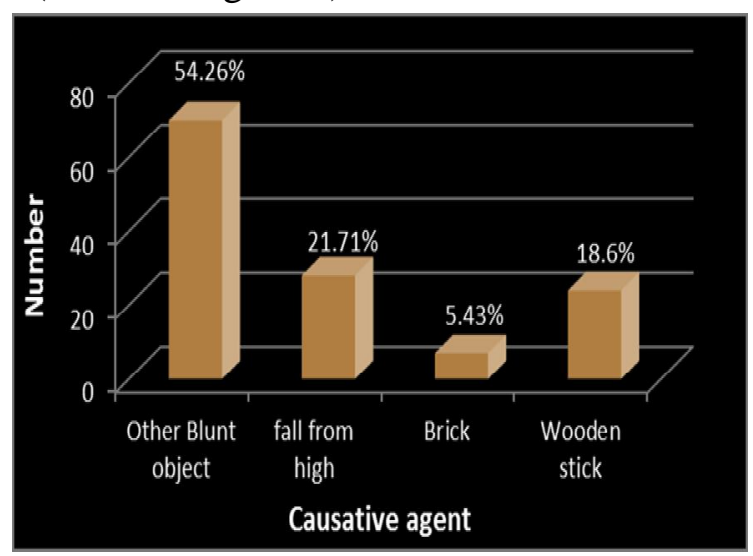

Figure (6): Distribution of the studied group according to the causative agent.

Season: Summer time had the highest fatal blunt head trauma (63-49\%), while autumn time had the lowest rate, i.e. 10 victims with $8 \%$ as seen in (figure 7). 
STATISTICAL STUDY OF FATAL BLUNT HEAD INJURIES IN GREAT CAIRO... 93

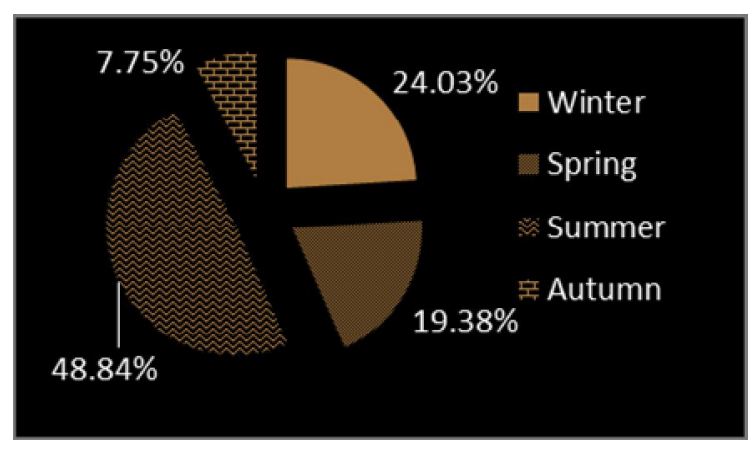

Figure (7): Distribution of the studied group according the season.

\section{DISCUSSION}

In the present study, we reviewed the autopsy reports of fatal traumatic head injuries that had been received at the morgue of Zeinhom, Cairo, Ministry of Justice during 2014 which were 129 cases out of total 2,128 cases examined in that year. The majority of the victims were in the 3rd decade (40 cases), 4th decade (39 cases) of age i.e. 79 victims which exceeded $60 \%$ of total victims. This could be explained by the fact that the period of the $3^{\text {rd }} \& 4^{\text {th }}$ decades is the period of peak activity in which people usually struggle, quarrel, are easily agitated and are subjected to accidents and assaults more than the older age. The young and middleaged groups largely consist of students and working people in various jobs, who usually travel by either own vehicles, buses or walk. Our results were more or less similar to results of Yattoo and Tabish (2008) who reported that head injuries deaths were highest in age group of $21-30$ years $(18.8 \%)$, followed by $11-$ 20 years age group (17.8\%) and $31-40$ years $(14.3 \%)$. Traumatic brain deaths were more common in males. Wu et al. (2008) stated that traumatic brain injury is the leading cause of traumatic injuries in
China and the 5th leading cause of mortality in adults less than 40 years old.

Vij et al. (2010) also concluded that the commonest age group affected was the 21-30 age group (28.1\%). The head was found to be the most common site of injury followed by the extremities, abdomen and chest. Akber et al. (2016) pointed out from their study at the morgue house of Dhaka medical college that the pattern of head injuries found in most cases belong to the younger age group i.e. 21-40 years with male preponderance. In contrary, Brown et al. (2008) reported that the highest rates of death and hospitalization due to traumatic brain injury were in people over age 65 year.

Verzeletti et al. (2014) analyzed data of 251 homicide victims recorded by the Brescia Institute of Forensic Medicine between the years 1982 and 2012 and found that victims were usually young (30\% was in the 21-30 years class)and males $(64 \%)$.

Kristoffersen et al. (2014) had done retrospective study from Western Norway on the cases of 196 homicide victims from 1985 to 2009. The median age of the victims was 35 years, in both genders. Within the cases, 113 of the victims were male and 83 female, 28 victims were under the age of 18 , The head was the body region most often injured in the homicide victims.

Our study showed that, the majority of cases, 93 cases, (72\%) were victims of homicide, while suicidal cases were 16 cases $(12.4 \%)$, and accidental fatal head trauma victims were $20(15.5 \%)$. Ben Khelil et al. (2017) in Tunisia studied 636 homicide victims who were autopsied at the Legal Medicine Department of 
Charles Nicolle Hospital in Tunisia, over a period of 10 years (2005-2014). Victims were males in $79.7 \%$ with a male-tofemale ratio of 3.93 , and the average age was 37.7 years. They reported that the most common methods of homicide were with the use of the sharp weapons $(51.7 \%)$, while blunt trauma inflicted with blunt instruments were found in (24.8\%).

Skull fractures were important indicators of severity of trauma in attacks to the head. Multiple bone fracture, comminuted fracture and base fractures were seen in homicide cases. Multiple cranial bones were involved in $69.3 \%$ cases. The presence or absence of a skull fracture, its type and site along with the type of intracranial haemorrhage has immense significance in the final outcome in cases of such head injuries (Saukko and Knight, 2015). In our study fissure fracture was detected in $46(34 \%)$ of cases, while combined fissure and depressed fractures were seen in $67(52 \%)$ of total cases. In the majority of our cases, $54(26 \%)$, the causative weapon was violent assaults with blunt objects. Twenty one cases were due to falls. Hitting with wooden stick was the weapon used in 18 cases (6\%). Using bricks as methods of inflicting head injuries and killing were seen in 7 cases $(5.43 \%)$. Chattopadhyay and Tripathi (2010) found in their study, that fissure fractures were found in $(13.6 \%)$ of their cases while fissure + depressed comminuted was found in (9.5\%). Akber et al. (2016) found in $(53 \%)$ of their cases that fractures of occipital bone were followed by parietal $(29 \%)$, frontal $(15 \%)$, while fractures of temporal bones were seen in (14\%).
Our study showed that in 10 cases (8\%) the only pathological finding seen was the intracranial haemorrhage and that 110 cases $(85 \%)$ died from brain damage, intracranial haemorrhage accompanied with skull fractures. In the study of Akber et al. (2016) extradural hemorrhage was seen in $43 \%$ of their study cases, followed by subdural, combination of all, subarachnoid and intra-cerebral hemorrhages.

Saukko and Knight (2015) reported that falls were extremely common. They found that the severity of head injuries not necessarily being directly related to the distance that the person falls. Many people die after falling from a standing position, yet others sometimes survive a fall of many meters. Death can follow from a head injury, especially onto the back of the head.

We observed that there was a high incidence of fatal head trauma in summer time $(48.84 \%)$ which is more than what was seen in winter $(24.03 \%)$ and the least incidence of trauma was in spring (19.38\%). Kasmaei et al. (2015) found in their study that spring was the season with highest incidence of fatal head trauma, and that falls was the most common mechanism of trauma $(62 \%)$.

\section{CONCLUSION}

From our study, it is recommended that complete dissection and documentation should be done to all deaths due to trauma especially head trauma by forensic pathologists and not only to the criminal suspicious cases to get more accurate data base about the characteristics feature of head injuries and the pattern of fatal traumatic head injuries. Complete histo- 


\section{STATISTICAL STUDY OF FATAL BLUNT HEAD INJURIES IN GREAT CAIRO... 95}

pathological study of different areas of the brain should be done for head trauma or even suspected head trauma cases. Autopsy should be performed as soon as possible to avoid loss of important findings due to autolysis of brain tissue.

\section{REFERENCES}

1. Akber EB , Alam MT, Rahman KM, Jahan I, Musa SA (2016): Pattern of Head Injuries (Cranio-cerebral) due to Homicide in Association with Other Injuries: A Retrospective Post-mortem Study Autopsied at Dhaka Medical College Morgue House., Mymensingh Med J., 25(2):296-302.

2. Ben Khelil M., Farhani F., Harzallah H., Allouche M., Gharbaoui M., Banasr A., Benzarti A. and Hamdoun M. (2017): Patterns of homicide in North Tunisia: a 10-year study (2005-2014), Injury Prevention, Pp 42123.

3. Brown A.W., Elovic E.P., Kothari S., Flanagan S.R. and Kwasnica C. (2008): Congenital and acquired brain injury. Epidemiology, pathophysiology, prognostication, innovative treatments and prevention. Archives of Physical Medicine and Rehabilitation, 89: S3-8.

4. Calvin H. K., Stephen K. H., George K., Stephanie N., Kevin K. W. and Ping K.L. (2012): Traumatic Brain Injury in the Elderly: Is it as Bad as we Think? Curr. Tran Geriatr Gerontol Rep., 1:171-178

5. Chattopadhyay S. P and Tripathi C. (2010): Skull fracture and haemorrhage pattern among fatal and nonfatal head injury assault victims - a critical analysis. J Inj. Violence Res. 2(2): 99103.

6. Hemalatha N. and Singh G. O. (2013): Patterns of Cranio-intracranial injuries In Fatal
Head Injury Cases. J Indian Acad Forensic Med. 35 (2):106-108

7. Kasmaei V. M., Asadi, P., Zohrevandi, B. and Raouf, M. T. (2015): An epidemiologic study of traumatic brain injuries in emergency department. Emergency, 3(4): 141-145.

8. Kranioti E.F. I. (2015): Forensic investigation of cranial injuries due to blunt force trauma: current best practice. Research and Reports in Forensic Medical Science, 5: 25-37.

9. Kristoffersen S. , Lilleng P.K. , M? hle B.O. and Morild I. (2014): Homicides in Western Norway, 1985-2009, time trends, age and gender differences. Forensic Sci Int., 238:1-8.

10. Saukko P. Knight B. (2015): Knights Forensic Pathology. $3^{\text {rd }}$ ed. Pbl. Edward Arnold Publishers, pp: 174-221.

11. Verzeletti A., Bin P. and De Ferrari F. (2014): Homicide by blunt trauma in Brescia county (northern Italy) between 1982 and 2012. Am J Forensic Med Pathol., 35(1):62-7

12. Vij A., Menon A., Menezes R.G., Kanchan T. and Rastogi P. (2010): A retrospective review of homicides in Mangalore, South India. J Forensic Leg Med., 17(6):312-5.

13. Wu, X., Hu J. and Zhuo L (2008):. Epidemiology of traumatic brain injury in eastern China, 2004: a prospective large case study. J Trauma, 64(5):1313-9.

14. Yattoo G.H. and Tabish A., (2008): The profile of head injuries and traumatic brain injury deaths in Kashmir. J Trauma Manag Outcomes, 2(1):1-9. 


\section{در اسة إحصائية لوفيات إصابات الر أس الرضية بمحافظة

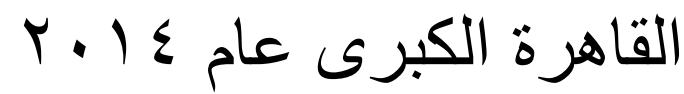

\section{راجح رضا عبد الله عوارة** ـ فؤاد حلمى الاباح ـ أشرف إبراهيم حسن}

قسم الطب الثرعي و السموم الإكلينيكية. كلية الطب الأزهر - ومصلدة الطب الثرعي بوزارة العدل*

خلفية البحث: تعتبر إصابات الرأس والعنق من بين أكثر وأهم الإصابات التي تثاهد في ممارسات

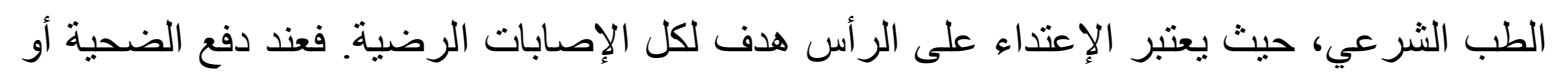

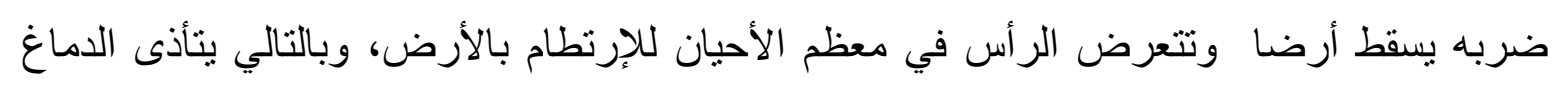

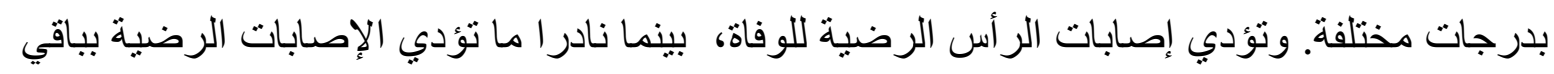
أجز اء الجسم للوفاة.

الهاف من البحث: يهدف البحث أساسا معرفة معدلات الجوانب الطبية الثرعية لحالات وفيات

إصابات الر أس و والتي قد يساعدنا على معرفة خصائصها وحجمها، ومن ثمة إيجاد الحلول لها. لها.

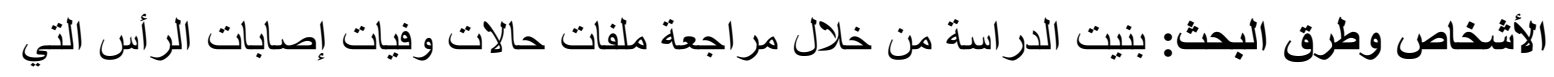

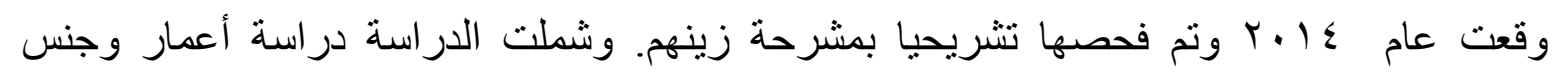

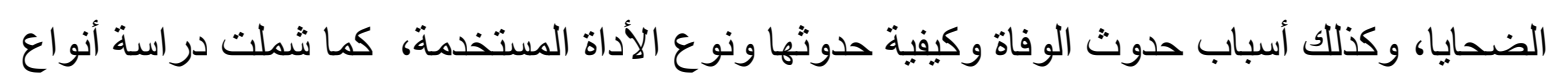
كسور الرأس، وكذلك موسم حدوثها.

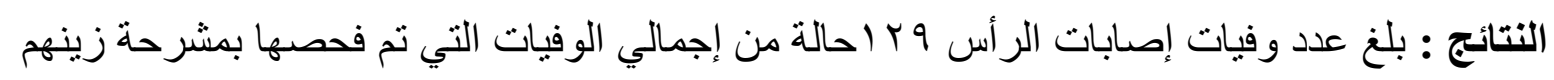

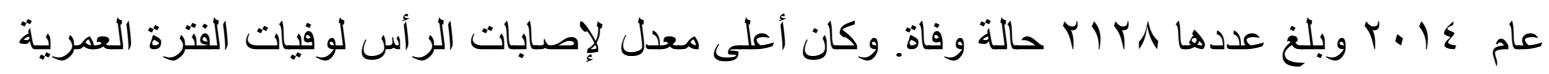

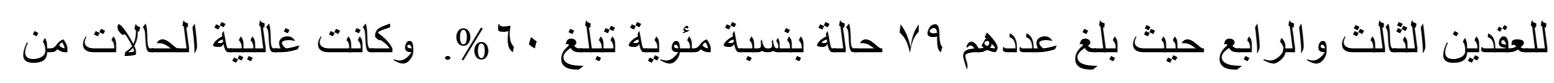

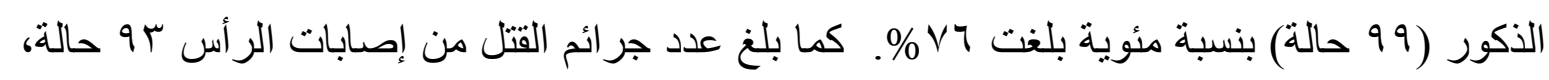

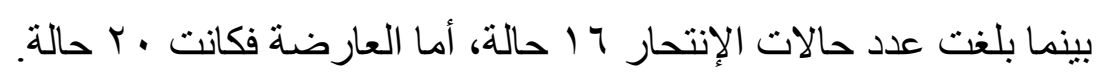

الإستتناج: الإصـابات الرضية للر أس تمثل تحدي للطبيب الثـرعي حيث يجب عليه أن ير اعي أن

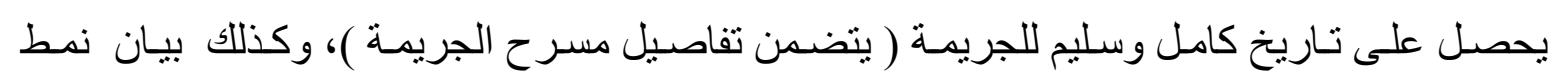

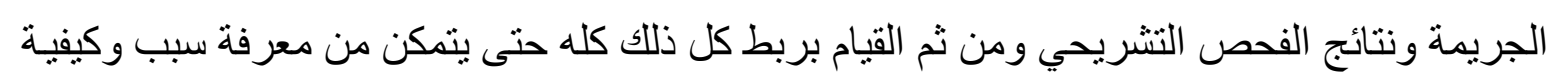

